\section{Asymptomatic infection in family contacts of patients with human visceral leishmaniasis in Três Lagoas, Mato Grosso do Sul State, Brazil}

\author{
Infecção assintomática em contactantes de \\ pacientes com leishmaniose visceral humana em \\ Três Lagoas, Mato Grosso do Sul, Brasil
}

\begin{abstract}
The Brazilian city of Três Lagoas, Mato Grosso do Sul State, has experienced an urban outbreak of visceral leishmaniasis since 2000. In 2002, due to the increase in the number of cases, 46 families with cases of visceral leishmaniasis were studied to verify the prevalence of asymptomatic infection in household contacts. Indirect immunofluorescence and ELISA showed a $36.4 \%$ positive infection rate. There were no cases of symptomatic disease among these contacts. There was no statistically significant difference in gender or age. Median age was 21 years, and the 10-19-year age bracket was the most heavily affected (23\%). As for family characteristics, no differences were observed in schooling or family income; most families (58.7\%) owned their homes, which were built of masonry (97.8\%) and had adequate infrastructure. All the families reported what were probably phlebotomine sand flies in the peridomicile. In conclusion, asymptomatic visceral leishmaniasis infection is frequent and occurs in both males and females, regardless of age.
\end{abstract}

Visceral Leishmaniasis; Communicable Diseases; Disease Outbreaks; Infection

\author{
Ana Lúcia Lyrio de Oliveira 1,2 \\ Anamaria Mello Miranda Paniago ${ }^{1}$ \\ Marcos Antônio Sanches 1 \\ Maria Elizabeth Cavalheiros Dorval ${ }^{3}$ \\ Elisa Teruya Oshiro ${ }^{3}$ \\ Cássia Rejane Brito Leal 4 \\ Fernando Henrique de Paula 1 \\ Luís Gustavo Pereira 1 \\ Rivaldo Venâncio da Cunha 1 \\ Márcio Neves Bóia 2,5
}

\section{Introduction}

Visceral leishmaniasis shows a worldwide distribution, affecting 65 countries 1 . The disease is transmitted through the bite of insects from genera Phlebotomus and Lutzomyia in the Old and New Worlds, respectively 2 . There are more than 30 vector species, with $\mathrm{Lu}$. longipalpis playing an outstanding role in the Americas ${ }^{3}$ and Phlebotomus spp. in the Old World ${ }^{4}$. In the late 1990s, $L u$. cruzi was incriminated as a vector in the municipality (county) of Corumbá, Mato Grosso do Sul State, Brazil 5.

Lu. longipalpis is spreading in Brazil, with widespread distribution in four regions: the North, Northeast, Southeast, and Midwest. It was initially a sylvatic species and is currently adapted to the urban environment in the peridomicile and intradomicile and in outbuildings with domestic animals 6,7.

In the Americas, visceral leishmaniasis is caused by Leishmania (Leishmania) chagasi, an obligatory intracellular protozoan. The disease is endemic in Brazil in more than 19 States, constituting an important public health problem, especially in Ceará, Bahia, Piauí, Maranhão, Rio Grande do Norte, Minas Gerais, and recently Mato Grosso do Sul and Tocantins 8,9,10.

Various control measures have been used, like vector control, culling of infected dogs with or without clinical manifestations of the disease, and early diagnosis and treatment of human pa- 
tients to minimize severity and reduce case-fatality. However, these measures have not proven effective, and new studies are under way with the aim of reducing the number of individuals at risk of acquiring the disease ${ }^{9,11}$.

Visceral leishmaniasis can be classified in three clinical forms, based on the hosts' clinical and laboratory characteristics: asymptomatic, or infection without clinical manifestations of the disease; oligosymptomatic or sub-clinical; and classical. The classical form of the disease is manifested by fever, weight loss, hepatosplenomegaly, and pancytopenia, and when not treated adequately can evolve to death 12,13 .

It is not known exactly why some cases of visceral leishmaniasis course as asymptomatic infection while others evolve to clinical illness. Host factors may determine this susceptibility, including nutritional status (e.g., vitamin A deficiency), host immune response, age, migrations, and co-infections such as with HIV 13,14,15,16,17.

Two studies in Brazil showed ratios of 18:1 and 11:1, respectively, between cases of infection without clinical manifestations and cases of classical disease 18,19 .

Asymptomatic infection is the most frequent clinical form and is normally associated with the presence of a case of visceral leishmaniasis in the family or vicinity, suggesting exposure to the same risk factors, including risk of infection between family members 15,20.

Based on the above, the current study aimed to estimate the percentage rate of asymptomatic infection in family contacts of visceral leishmaniasis patients and the epidemiological conditioning factors for acquiring the infection in Três Lagoas, a municipality (county) in Mato Grosso do Sul State, Brazil, where the disease has spread recently, with autochthonous cases confirmed in October 2000, and where it has expanded rapidly and is difficult to control 21. Importantly, no autochthonous cases of tegumentary leishmaniasis have been reported in the same municipality of Três Lagoas.

\section{Subjects and methods}

A cross-sectional epidemiological study was conducted from January 1 to July 30, 2002, in the urban area of the municipality of Três Lagoas, where visceral leishmaniasis was already epidemic.

\section{Description of the study area}

The city of Três Lagoas (20.75o S; 51.67o W), with an area of $10,207 \mathrm{~km}^{2}$, is located on a plain in the eastern region of the State of Mato Grosso do Sul, bordering on the State of São Paulo and $324 \mathrm{~km}$ from the State capital, Campo Grande. Total population is 79,059 , with a population density of 7.73 inhabitants $/ \mathrm{km}^{2}$. The main source of income is cattle-raising, and recent incipient industrial growth has led to local population growth 22 .

The climate is hot, humid, and tropical, with the rainy season in the summer and dry season in the winter. Total annual precipitation varies from $900 \mathrm{~mm}$ to $1,400 \mathrm{~mm}$. The yearly quarter with the heaviest rainfall is November, December, and January. The predominant plant cover is uniform, with clear fields, savannah, and evergreen forest 22 .

\section{Study population}

The study included 46 of the 60 families with patients with clinical manifestations of visceral leishmaniasis from January to July 2002, confirmed by the Três Lagoas Municipal Health Department.

A questionnaire was applied to family members of visceral leishmaniasis patients, including personal identification data, symptoms, and epidemiological characteristics such as: type ofdwelling, occupational conditions, general household characteristics, proximity to forests, presence of animals and probable phlebotomine sand flies in the domicile and peridomicile, sewage and waste disposal, family income, schooling, and time/frequency spent by children outdoors. As for questions on the possible presence of sand flies in the domicile or peridomicile, subjects were asked to describe the insect, and the answer was only considered positive when the description matched this vector, with the following principal parameters (small insect, from $1 \mathrm{~mm}$ to $3 \mathrm{~mm}$, light color, covered with bristles, low-flying).

Confirmed cases of visceral leishmaniasis were based on clinical manifestations of the parasitosis, associated with observation of amastigote forms in Giemsa-stained bone marrow smears or serology with indirect immunofluorescence (IIF) with a titer of $\geq 1: 80$.

Families were excluded if they refused to sign the informed consent, changed addresses, or were not located.

The study was approved by the Institutional Review Board of the Federal University in Mato Grosso do Sul.

\section{Sero-epidemiological survey}

Blood samples were drawn from 220 family members and analyzed with IIF and enzyme-linked immunosorbent assay (ELISA). 
IIF was performed with the Biomanguinhos kit (Biomanguinhos, Oswaldo Cruz Foundation, Rio de Janeiro, Brazil) according to the manufacturer's instructions, with control and test sera at dilutions of 1:40 and 1:80, adding the anti-IgG/ fluorescein conjugate at 1:100. ELISA was performed at the Cell Ultrastructure and Biology Laboratory of the Oswaldo Cruz Institute, Oswaldo Cruz Foundation, in Rio de Janeiro, Brazil.

Cases of asymptomatic infection were defined as those with IIF serology titer $\geq 1: 80$ and/ or ELISA with a titer greater than 0.305 (cutoff: 0.278).

\section{Statistical analysis}

Data were stored in Excel 2007 (Microsoft Corp., USA) and tabulated in BioEstat 4.0 (Sociedade Civil Mamirauá, Manaus, Brazil). Categorical variables were analyzed with the $\chi^{2}$ test with Yates correction, with significance set at $\mathrm{p}<0.05$. The other variables were analyzed with the Student t, ANOVA, Mann-Whitney, and Kruskal-Wallis tests, according to normality and number of variables.

\section{Results}

All the interviewees were asymptomatic contacts of visceral leishmaniasis cases. The serological methods showed a $36.4 \%$ positive infection rate (Table 1). These asymptomatic individuals were followed up for six months and remained symptom-free.

The number of contacts per household varied from 2 to 12 persons, with a median of 5 individuals per household. Median age was 21 years.
No statistically significant difference was observed in distribution by gender or age bracket (Table 1).

As for the social and epidemiological characteristics of the families, there was a higher (but statistically non-significant) infection rate in families whose head-of-household had complete primary or incomplete secondary schooling and family income of 3 to 5 times the minimum wage (Table 2).

The majority of families (58.7\%) owned their homes, most of which were built of masonry $(97.8 \%)$, with ceramic roof tiles, running water, and public garbage collection (97.8\%), while $95.7 \%$ had septic tanks and $100 \%$ had electricity. Some homes had vegetation in the domicile (34.8\%) and $26 \%$ were located close to the forest.

A total of $82.2 \%$ of the families reported that the children played outdoors in the late afternoon/dusk. Some $56 \%$ of the households had dogs, while other domestic animals included cats $(19.5 \%)$, horses $(13 \%)$, and chickens (13\%) (Table 2). Among the infected contacts there was a statistically significant difference between those that had pet dogs $(60.2 \%)$ and those without dogs in the household (39.8\%) ( $p=0.003$ ), as well as in the households that had a stove, TV set, and refrigerator and those with 4 to 6 rooms (Table 2).

The accumulation of garbage in the peridomicile was not a risk factor for infection, which was more frequent in the households without accumulated garbage (Table 2).

The presence of insects suggestive of sand flies was reported in all the households.

The mean number of contacts per household was similar in relation to the various epidemiological and social variables, except for a statistically significant difference as to home ownership,

Distribution by age bracket, gender, and seropositive rate for family contacts of visceral leishmaniasis contacts in the municipality of Três Lagoas, Mato Grosso do Sul State, Brazil, 2002.

\begin{tabular}{|c|c|c|c|c|c|c|c|c|}
\hline \multirow[t]{2}{*}{ Age bracket (years) } & \multicolumn{2}{|c|}{ Examined } & \multicolumn{2}{|c|}{ Seropositive } & \multicolumn{2}{|c|}{ Females $(n=115)$} & \multicolumn{2}{|c|}{ Males $(n=105)$} \\
\hline & $\mathbf{N}$ & $\%$ & $\mathrm{n}$ & $\%$ & Positive & Negative & Positive & Negative \\
\hline$\leq 4$ & 31 & 14.1 & 12 & 38.7 & 6 & 14 & 6 & 5 \\
\hline 5 to 9 & 22 & 10.0 & 8 & 36.4 & 6 & 7 & 2 & 7 \\
\hline 10 to 19 & 51 & 23.2 & 26 & 50.9 & 11 & 10 & 15 & 15 \\
\hline 20 to 29 & 38 & 17.2 & 11 & 28.9 & 6 & 13 & 5 & 14 \\
\hline 30 to 59 & 62 & 28.2 & 18 & 29.0 & 12 & 22 & 6 & 22 \\
\hline$\geq 60$ & 16 & 7.3 & 5 & 31.2 & 3 & 5 & 2 & 6 \\
\hline Total & 220 & 100.0 & 80 & 36.4 & 44 & 71 & 36 & 69 \\
\hline
\end{tabular}


Epidemiological and social characteristics of 46 family contacts of visceral leishmaniasis cases in the municipality of Três Lagoas, Mato Grosso do Sul State, Brazil, 2002.

\begin{tabular}{|c|c|c|c|c|c|c|}
\hline Characteristics & $\begin{array}{c}\text { Households } \\
\text { (number of } \\
\text { contacts) }\end{array}$ & $\begin{array}{l}\text { Positive for visceral } \\
\text { leishmaniasis } \\
\text { infection (\%) }\end{array}$ & $p$ & $\begin{array}{l}\text { Mean } \\
\text { contacts per } \\
\text { household }\end{array}$ & $\begin{array}{l}\text { Standard } \\
\text { deviation }\end{array}$ & p \\
\hline \multicolumn{7}{|l|}{ Dog(s) in household } \\
\hline Present & $26(128)$ & 60.2 & 0.003 & 4.9 & 2.13 & 0.431 * \\
\hline Absent & $20(92)$ & 39.8 & & 4.6 & 2.25 & \\
\hline \multicolumn{7}{|l|}{ Accumulated garbage } \\
\hline Absent & $30(143)$ & 67.5 & 0.000 & 4.8 & 1.57 & $0.320 * \star$ \\
\hline Peridomicile & $16(77)$ & 32.5 & & 4.4 & 1.31 & \\
\hline \multicolumn{7}{|l|}{ Monthly family income } \\
\hline \multicolumn{7}{|l|}{ (number of times minimum wage) } \\
\hline 1 to 2 & $23(111)$ & 30.2 & 0.431 & 5.0 & 1.80 & $0.445^{\star \star \star}$ \\
\hline 3 to 5 & $11(45)$ & 37.7 & & 4.2 & 1.08 & \\
\hline$>5$ & $10(50)$ & 28.0 & & 5.0 & 2.67 & \\
\hline Unknown & $4(14)$ & 04.1 & & - & - & \\
\hline \multicolumn{7}{|l|}{ Number of rooms } \\
\hline 2 to 3 & $4(16)$ & 6.3 & 0.000 & 4.0 & 1.15 & $0.210 * \star \star$ \\
\hline 4 to 6 & $28(123)$ & 65.0 & & 4.4 & 1.62 & \\
\hline$>7$ & $14(81)$ & 28.7 & & 5.8 & 2.87 & \\
\hline \multicolumn{7}{|l|}{ Household assets } \\
\hline Stove, refrigerator, or TV & $7(36)$ & 17.5 & 0.000 & 5.14 & 1.77 & $0.187^{\star \star \star \star}$ \\
\hline Stove, TV, refrigerator & $36(162)$ & 76.3 & & 4.5 & 1.97 & \\
\hline Stove, TV, refrigerator, stereo & $3(22)$ & 6.2 & & 7.3 & 4.04 & \\
\hline \multicolumn{7}{|l|}{ Schooling (head of family) } \\
\hline Incomplete primary & $21(92)$ & 35.0 & 0.080 & 4.4 & 1.32 & $0.080 * \star \star$ \\
\hline \multicolumn{7}{|l|}{ Complete primary plus } \\
\hline incomplete secondary & $9(55)$ & 37.5 & & 6.1 & 2.57 & \\
\hline Secondary and university & $5(27)$ & 15.0 & & 5.4 & 1.67 & \\
\hline Not reported & $11(46)$ & - & & 4.2 & - & \\
\hline \multicolumn{7}{|l|}{ Home ownership } \\
\hline \multirow[t]{2}{*}{ Own } & $27(148)$ & 61.3 & 0.000 & 5.5 & 2.12 & $\mathrm{X}$ between \\
\hline & & & & & & 1 and $3=0.01 \#$ \\
\hline On loan & $8(34)$ & 20.0 & & 5.5 & 2.14 & \\
\hline Rented & $11(38)$ & 18.7 & & 3.7 & 0.90 & \\
\hline
\end{tabular}

* Mann-Whitney test;

** Student t test;

$\star \star \star *$ Kruskal-Wallis test;

\# ANOVA.

with a prevalence of families that owned their own homes as opposed to renting (Table 2).

\section{Discussion}

The urbanization of visceral leishmaniasis has motivated discussion and implementation of control measures throughout Brazil, but the results have been limited and largely ineffective 23 .
The disease is currently spreading unchecked, mainly in urban areas in the Southeast and Midwest 24 .

Asymptomatic infection rates in family contacts were similar in relation to gender, while the clinical disease itself in Três Lagoas during the same period was twice as frequent in males (43 female patients and 106 males). The same was true for age bracket; namely, there was no statistically significant difference in the positive con- 
tacts, while among patients the incidence rate in the 0 -4-year bracket was $5.9 /$ thousand as compared to 1.8 /thousand from 10 to 19 years and over 60 years of age 21 . Similar results were found in the States of Bahia and Minas Gerais 25,26.

The explanation for this difference between visceral leishmaniasis cases with the classical versus asymptomatic forms may lie in the type of host cellular immune response 27. Another hypothesis is that genetic factors are involved in development of the clinical disease. Recent studies in a mouse model show that these factors may influence the development of the clinical forms of visceral leishmaniasis, although they have not been fully explained 28,29 .

The infection rates found in this study are important and worrisome, suggesting that individuals exposed to infection or already infected may be as important as those that develop the disease, due to the risk of their acting as reservoirs for transmitting the parasite 23,30,31,32.

As for the social and epidemiological characteristics of the households studied in Três Lagoas, although masonry homes with adequate infrastructure were widespread in the municipality, the family income and schooling levels were low. Various studies have shown similarities in family income and schooling, but differences in housing infrastructure 18,26,33.

As reported by the subjects, insects suggestive of phlebotomines were present in the peridomicile in all the households, demonstrating the vector's importance in the visceral leishmaniasis transmission chain, as observed in Teresina (Piauí State, Brazil) 34, Sabará (Minas Gerais State, Brazil) 25, and Sudan 12. These findings further corroborate the observations by Costa \& Vieira 11 and Tesh 35 , that vector control has been ineffective in reducing the parasite's transmission or avoiding new epidemic areas.

One of the probable causes of the difficulty in controlling the proven visceral leishmaniasis vector $L u$. longipalpis is that it is frequently found in the anthropic environment and in animal shelters, which serve as a source of food and shelter for the insect $36,37,38$. The presence of children outdoors at dusk, dogs and other domestic animals, and plant cover in the domicile or vicinity, as observed in the study site, can play an important role in the visceral leishmaniasis transmission chain, as already shown in other areas where the disease occurs 33,34,39.

In conclusion, the current study has shown that asymptomatic visceral leishmaniasis infection is frequent, occurring in both males and females and in all age brackets, which does not suggest occupational exposure. Further research is required on potential factors to explain the higher incidence of the clinical disease in men and young children, and on the role that individuals with asymptomatic infection play in the visceral leishmaniasis transmission chain. 


\section{Resumo}

O Município de Três Lagoas, Mato Grosso do Sul, Brasil, foi alvo de uma epidemia de leishmaniose visceral a partir de 2000. Em 2002, devido ao incremento de casos, estudou-se 46 famílias que apresentavam um caso de doença para verificar-se o percentual de positividade de infecção assintomática por leishmaniose visceral em contactantes. Encontrou-se 36,4\% de positividade pelos testes sorológicos Reação de Imunofluorescência Indireta elou imunoenzimático ELISA, sem diferença estatisticamente significativa quanto ao sexo e faixa etária. A mediana de idade foi de 21 anos, sendo a faixa etária mais acometida de 10 a 19 anos (23\%). Quanto às características familiares não observaram-se diferenças quanto ao nível de instrução $e$ renda familiar; a moradia, em sua maioria, era própria (58,7\%), em alvenaria (97,8\%), com infra-estrutura adequada. Todas as famílias relataram a presença de provável flebotomíneo no peridomicílio. Conclui-se que a infecção assintomática por leishmaniose visceral é freqüente, ocorrendo em homens e mulheres, independente de faixa etária.

Leishmaniose Visceral; Doenças Transmissíveis; Surtos de Doenças; Infecção

\section{References}

1. Desjeux P. Leishmaniasis: current situation and new perspectives. Comp Immunol Microbiol Infect Dis 2004; 27:305-18.

2. Desjeux P. Human leishmaniases: epidemiology and public health aspects. World Health Stat Q 1992; 45:267-75.

3. Uribe S. The status of the Lutzomyia longipalpis species complex and possible implications of Leishmania transmission. Mem Inst Oswaldo Cruz 1999; 94:729-34.

4. Herwaldt B. Leishmaniasis. Lancet 1999; 354: 1191-9.

5. Santos SO, Arias J, Ribeiro AA, Hoffmann MP, Freitas RA, Malacco MAF. Incrimination of Lutzomyia cruzi as a vector of American Visceral Leishmaniasis. Med Vet Entomol 1998; 12:315-7.

6. Lainson R, Rangel EF. Ecologia das leishmanioses, Lutzomyia longipalpis e a eco-epidemiologia da leishmaniose visceral americana (LVA) no Brasil. In: Rangel EF, Lainson R, organizadores. Flebotomíneos no Brasil. Rio de Janeiro: Editora Fiocruz; 2003. p. 311-36.

7. Oliveira AG, Andrade Filho JD, Falcão AL, Brazil RP. Estudo de flebotomíneos (Diptera, Psychodidae, Phlebotominae) na zona urbana da cidade de Campo Grande, Mato Grosso do Sul, Brasil, 19992000. Cad Saúde Pública 2003;19:933-44.

\section{Contributors}

A. L. L. Oliveira coordinated the research and - together with R. V. Cunha and M. N. Bóia - participated in all its stages: design, elaboration of the research instrument, data collection, planning and performance of the laboratory tests, and writing of the paper. A. M. M. Paniago, M. A. Sanches, F. H. Paula, and L. G. Pereira participated in the elaboration of the research instruments, fieldwork with clinical and epidemiological evaluation, and data preparation and processing. M. E. C. Dorval, E. T. Oshiro, and C. R. B. Leal collaborated in the planning, laboratory processing of all the samples, and writing of the paper. All the authors participated in the article's final revision.

\section{Acknowledgments}

The authors wish to thank the Department of Cell Ultrastructure and Biology, Oswaldo Cruz Institute, Oswaldo Cruz Foundation, for performing the ELISA tests, the Três Lagoas Municipal Health and Vector Control Departments and the Vector Control Division of the Mato Grosso do Sul State Health Department for providing logistical support and data, and the Department of Science and Technology of the Brazilian Ministry of Health (DECIT - MS) for financial support.
8. Costa JML, Viana GMC, Saldanha ACR, Nascimento MDSB, Alvim AC, Burattini MN, et al. Leishmaniose visceral no estado do Maranhão, Brasil: a evolução de uma epidemia. Cad Saúde Pública 1995; 11:321-4.

9. Departamento de Vigilância Epidemiológica, Secretaria de Vigilância em Saúde, Ministério da Saúde. Manual de vigilância e controle da leishmaniose visceral. Brasília: Secretaria de Vigilância em Saúde, Ministério da Saúde; 2003. (Série A, Normas e Manuais Técnicos)

10. Werneck GL, Rodrigues Jr. L, Santos MV, Araújo IB, Moura LS, Lima SS, et al. The burden of Leishmania chagasi infection during an urban outbreak of visceral leishmaniasis in Brazil. Acta Trop 2002; 83:13-8.

11. Costa CHN, Vieira JBF. Mudanças no controle da leishmaniose visceral no Brasil. Rev Soc Bras Med Trop 2001; 34:223-8.

12. Bucheton B, Kheir MM, El-Safi SH, Hammad A, Mergani A, Mary C, et al. The interplay between environmental and host factors during an outbreak of visceral leishmaniasis in eastern Sudan. Microbes Infect 2002; 4:1449-57.

13. Murray HW, Berman JD, Davies CR, Saravia NG. Advances in leishmaniasis. Lancet 2005; 366: 1561-77. 
14. Alvar J, Canavate C, Gutierrez-Solar B, Jimenez M, Laguna F, Lopez-Velez R, et al. Leishmania and human immunodeficiency virus coinfection: the first 10 years. Clin Microbiol Rev 1997; 10:298-319.

15. Costa CHN, Pereira HF, Araújo MV. Epidemia de leishmaniose visceral no Estado do Piauí, Brasil, 1980-1986. Rev Saúde Pública 1990; 24:361-72.

16. Guerin PJ, Olliaro P, Shyam S, Boelaert M, Croft S, Desjeux P, et al. Visceral leishmaniasis: current status of control, diagnosis, and treatment, and a proposed research and development agenda. Lancet Infect Dis 2002; 2:494-500.

17. Luz KG, Succi RCM, Torres E. Nível sérico da vitamina A em crianças portadoras de leishmaniose visceral. Rev Soc Bras Med Trop 2001; 34:381-4.

18. Badaró R, Jones TC, Carvalho EM, Sampaio D, Reed SG, Barral A, et al. New perspectives on a subclinical form of visceral leishmaniasis. J Infect Dis 1986; 154:1003-11

19. Marzochi MCA, Marzochi KBF. Tegumentary and visceral leishmaniases in Brazil: emerging anthropozoonosis and possibilities for their control. Cad Saúde Pública 1994; 10 Suppl 2:S359-75.

20. Caldas AJM, Silva DRC, Pereira CCR, Nunes PMS, Silva BP, Silva AAM, et al. Infecção por Leishmania (Leishmania) chagasi em crianças de uma área endêmica de leishmaniose visceral americana na Ilha de São Luis-MA, Brasil. Rev Soc Bras Med Trop 2001; 34:445-51.

21. Oliveira ALL, Paniago AMM, Dorval MEC, Oshiro ET, Leal CRB, Sanches M, et al. Foco emergente de leishmaniose visceral em Mato Grosso do Sul, Brasil. Rev Soc Bras Med Trop 2006; 39:446-50.

22. Instituto Brasileiro de Geografia e Estatística. Estatísticas da saúde: cidades. http://www.ibge. gov.br/cidadesat/default.php (accessed on 10/ Mar/2006)

23. Costa CHN, Stewart JM, Gomes RB, Garcez LM, Ramos PK, Bozza M, et al. Asymptomatic human carriers of Leishmania chagasi. Am J Trop Med Hyg 2002; 66:334-7.

24. Gontijo CMF, Melo MN. Leishmaniose visceral no Brasil: quadro clínico, desafios e perspectivas. Rev Bras Epidemiol 2004; 7:338-49.

25. Moreno EC, Melo MN, Genaro O, Lambertucci JR, Serufo JC, Andrade ASR, et al. Risk factors for Leishmania chagasi infection in a urban area of Minas Gerais State. Rev Soc Bras Med Trop 2005; 38:456-63.

26. D’Oliveira Jr. A, Costa SRM, Barbosa AB, Orge MGO, Carvalho EM. Asymptomatic Leishmania chagasi infection in relatives and neighbors of patients with visceral leishmaniasis. Mem Inst Oswaldo Cruz 1997; 92:15-20.
27. Alexander J, Bryson K. T helper (h)1/Th2 and Leishmania: paradox rather than paradigm. Immunol Lett 2005; 99:17-23.

28. Blackwell JM. Genetic susceptibility to leishmanial infections: studies in mice and man. Parasitology 1996; 112 Suppl:S67-74.

29. Lipoldová M, Svobodová M, Kruvolá M, Havelková H, Badalová J, Nohýnková E, et al. Susceptibility to Leishmania major infection in mice: multiple loci and heterogeneity of immunopathological phenotypes. Genes Immun 2000; 1:200-6

30. Desjeux P. Leishmaniasis: public health aspects and control. Clin Dermatol 1996; 14:417-23.

31. Otero AC, Silva VO, Luz KG, Palatnik M, Pirmez C, Fernandes O, et al. Short report: occurrence of Leishmania donovani DNA in donated blood from seroreactive Brazilian blood donors. Am J Trop Hyg 2000; 62:128-31.

32. Sharma MC, Gupta AK, Das VNR, Verma N, Kumar $\mathrm{N}$, Saran R, et al. Leishmania donovani in blood smears of asymptomatic persons. Acta Trop 2000; 76:195-6.

33. Caldas AJM, Costa JML, Silva AAM, Vinhas V, Barral A. Risk factors associated with asymptomatic infection by Leishmania chagasi in north-east Brazil. Trans R Soc Trop Med Hyg 2002; 96:21-8.

34. Werneck GL. Spatial approaches to study the epidemiology of visceral leishmaniasis in Teresina, Brazil [Doctoral Dissertation]. Boston: Harvard School of Public Health; 2000.

35. Tesh RB. Control of zoonotic visceral leishmaniasis: is it time to change strategies? Am J Trop Med Hyg 1995; 52:287-92.

36. Azevedo ACR, Monteiro FA, Cabello PH, Souza NA, Rosa-Freitas MG, Rangel EF. Studies on populations of Lutzomyia longipalpis (Lutz \& Neiva, 1912) (Diptera: Psychodidae: Phlebotominae) in Brazil. Mem Inst Oswaldo Cruz 2000; 95:305-22.

37. Galati EAB, Nunes VLB, Cristaldo G, Da Rocha HC. Aspectos do comportamento da fauna flebotomínea (Diptera: Psychodidae) em foco de leishmaniose visceral e tegumentar na Serra de Bodoquena e área adjacente, Estado de Mato Grosso do Sul, Brasil. Rev Patol Trop 2003; 32:235-61.

38. Sherlock IA. Ecological interactions of visceral leishmaniasis in the State of Bahia, Brazil. Mem Inst Oswaldo Cruz 1996; 91:671-83.

39. Cerbino Neto J. Fatores associados à incidência de leishmaniose visceral em Teresina - PI na década de 90 [Masters Thesis]. Rio de Janeiro: Universidade Federal do Rio de Janeiro; 2003.

Submitted on $11 /$ Jun/2007

Final version resubmitted on 22/Nov/2007

Approved on 05/Dec/2007 